\title{
Origins, Evolution and Current Activities of Sunni Salafi Jihadist Groups in Bangladesh
}

\section{Labiba Rahman}

Schar School of Policy and Government, George Mason University, VA 22030, USA

Corresponding Contact:

Email: Irahmanp@masonlive.gmu.edu

\begin{abstract}
Despite its global recognition as a moderate Muslim country, Bangladesh has been experiencing increasing bouts of religious fundamentalism and militant activities since 2005. This phenomenon is not altogether novel to the country. During the Liberation War of 1971, Bengali freedom fighters faced staunch opposition from the Pakistani armed forces as well as Islamist militias under the control of Jamaat-e-Islami, an Islamist political party. Even after attaining its independence, Bangladesh has struggled to uphold the pillars of democracy and secularism due to political, social and religious drivers. Between January 2005 and June 2015, nearly 600 people have died in Islamic terrorist attacks in the country. These militant outfits either have close ties to or are part of $\mathrm{Al}$ Qaeda Indian Subcontinent (AQIS) and the Islamic State (ISIS). Despite such troubling signs and the fact that it is the fourth largest Muslim majority country in the world, Bangladesh has generally received little attention from academics of security studies. This paper aims to provide a comprehensive analysis of the drivers and trends of Sunni Salafi jihadist groups operating in Bangladesh to ascertain the implications for counterterrorism activities. Political, social and religious interventions that go beyond the hard approach must be undertaken to control the mounting threat of Islamist terrorism to the security and stability of the nation.
\end{abstract}

Keywords: Religious Terrorism, Bangladesh, Radicalization, Political Islam, Al Qaeda, ISIS

9/17/2018

Source of Support: Nil, No Conflict of Interest: Declared

This article is is licensed under a Creative Commons Attribution-NonCommercial 4.0 International License.

Attribution-NonCommercial (CC BY-NC) license lets others remix, tweak, and build upon work non-commercially, and

although the new works must also acknowledge \& be non-commercial.

\section{INTRODUCTION}

A small country in South Asia, Bangladesh is home to more than 150 million Muslims who comprise approximately $88.8 \%$ of the population. The remainder of the people are followers of Hinduism, Christianity, and Buddhism (BBS, 2012). For 15 years, Bangladesh was under military rule until democracy was established in 1990 (BBC News, 2017). Since then the country has been the site for confrontational politics and rampant corruption at the hands of its two main political parties, Awami League (AL) and Bangladesh Nationalist Party (BNP). Despite these obstacles, Bangladesh has witnessed a robust economic growth of an average of $6 \%$ per year. This growth has been driven by a rise in 
readymade garments exports, foreign workers' remittances and domestic consumption. In 2015 , it gained the status of lower middle-income country with $31.5 \%$ of the population living below the national poverty line (ADB, 2017).

Despite its global recognition as a moderate Muslim country, Bangladesh has been experiencing increasing bouts of religious fundamentalism and militant activities since 2005. Nearly 600 people have died in Islamic terrorist attacks between January 2005 and June 2015; 90\% of which have taken place since 2013 (South Asia Terrorism Portal, 2016). While these incidents indicate the mounting threat of Islamic terrorism to the security and stability of the nation, this is not a novel concept for Bangladesh. The next section of this paper will address the history of Islamic extremism and militant violence in Bangladesh since its liberation from Pakistan in 1971.

The research for this paper has been conducted largely from secondary sources, including journal articles, op-eds, and reports from independent analysts and academic literature. Content from two widely circulating newspapers in Bangladesh, the Daily Star, and Dhaka Tribune, as well as BBC News and the Indian Express, has been used to supplement the findings. Information from verified internet sources such as the U.S. Department of State and Bangladesh Bureau of Statistics (BBS) has also been analyzed for this paper.

\section{Islamist Political History of Bangladesh}

The history of the nation is tainted with Islamist political violence. After the 1947 British Partition of the British Raj, the Pakistan that came to be was fragmented into two territories: East Pakistan and West Pakistan. Soon tensions emerged between the Bengali ethnic majority of East Pakistan and Islamic nationalists of West Pakistan. After suffering through decades of discriminatory policies, economic deprivation, and military crackdown, the Bengalis declared civil war on West Pakistan (Schendel, 2009). Bengali freedom fighters (Mukti Bahini) faced staunch opposition from Pakistani armed forces as well as Islamist militias led by the Islamist political party, the Jamaat-e-Islami (Jamaat). In the nine-month long war that ensured, approximately three million people were killed, 200,000 women were raped, and roughly 10 million were compelled to flee the country (Roychowdhury, 2016). Many of the perpetrators of extreme violence and atrocities against civilians were members of Jamaat. Prominent Jamaat leader Ghulam Azam created and led Islamist militia against Bengalis in the East culminating in numerous murders and cases of rape. Motiur Rahman Nizami, the then president of the party's student wing, was convicted and later tried for killing 480 people and committing torture during the Liberation War. His fellow former student wing member, Abdul Kader Mullah, also known as the "Butcher of Mirpur", was accused and later hung for torturing and killing 344 civilians in Dhaka's Mirpur Area alone (BBC News, 2016). Soon after attaining independence in December of 1971, the Father of the Nation, Sheikh Mujibur Rahman, proscribed Jamaat due to its contribution in the Bengali genocide. The Constitution of Bangladesh was established in 1972 upholding secularism and democracy as the main principles (Huque and Akhter, 1987).

The blow to the democracy of Bangladesh came just four years after independence when a military coup resulted in the assassination of the Sheikh Mujibur Rahman on August 14, 1975. The assassination promptly lead to a period of military dictatorship under Major Zia-ur Rahman and his political party, BNP, from 1975 to 1981 (Fair et al., 2016). At that time, a slow, populist movement away from secularism was occurring; the primary reason 
for which was the lack of scholarly literature on politics and religion (Khan, 2017). President Zia took this opportunity to strategically use Islam as a political to gain support from a population reverting to its religious inclinations. He proceeded to make substantial changes to the Constitution aimed at eliminating the role of secularism in the state (Khan, 1976). Furthermore, he allowed the legalization and participation of many religious parties in politics (Riaz, 2010). One of these was the Bangladeshi wing of Jamaat-e-Islami (BJI) whose main aim was to transform Bangladesh into an Islamic State. In the process, President Zia turned a blind eye towards the growing radicalization in the country and the crimes these groups were committing (Singh, 2015). President Zia was assassinated in 1981 leaving behind a legacy of nationalism and governance embedded in Islam.

A period of quasi-military governance under General Hussain Mohammad Ershad ensued from 1982 to 1990 which further cemented this phenomenon. During his time in power, President Ershad claimed Islam to be Bangladesh's state religion and appointed two Jamaat war criminals to the cabinet (Swami, 2013). However, mass protests and demand for restoration of democracy led to President Ershad transferring his power to a caretaker government. In the meantime, Sheikh Mujibur Rahman's daughter, Sheikh Hasina Wazed, took over leadership of her father's political party AL. In 1991, the widow of President Zia, Begum Khaleda Zia, led BNP to win the first democratic election of Bangladesh in 15 years. The main goal of BNP to entrench Islam into Bangladesh's national identity clashed with the secular Bengali nationalism favored by AL. The two mainstream political parties have been intense rivals ever since (Riaz, 2010).

\section{DeVELoPMENT OF ISLAMIST MiLITANCY IN BANGLADESH}

Scholarly literature examining the drivers of violent groups has identified ethnic conflicts (Horowitz, 1985), state repression (Scott, 1976), grievances (Gurr, 1970), individual-level factors (Fair et al., 2016), global expansion of Wahhabi Islamic seminaries (Singh, 2015) and lack of a formalized governmental framework (Khan, 2017). Several academics have argued that there is a high likelihood of impoverished individuals aligning with militant organizations due to feelings of disenfranchisement and general dissatisfaction with the existing political structure (Abadie, 2006). Opportunity cost also plays an important role especially for those living in poverty. All things remaining equal, disadvantaged individuals have lower opportunity costs associated with engaging in political violence than their wealthier counterparts, thus increasing the chances of them doing so (Gates, 2002).

This paper argues that five waves of radicalization resulted in the upsurge of Sunni Salafi jihadist groups in Bangladesh. With the rise in political Islam, Bangladesh became the ideal breeding ground for extremist behavior. Under the military era of Bangladesh, BJI became the nation's largest Islamist party. The group promoted extremist Islamic policies which became the taproot of many of Bangladesh's Islamist militant outfits. Also, the association of BJI with the government opened the door for oil-rich Arab states to invest in the nation. They provided financial and developmental aid particularly in the scope of building new mosques and Islamic seminaries (madrassahs) (Hasan, 2011). It was in these Arab funded religious institutes that the first wave of radical Islam or Wahhabism truly began. Wahhabism, named after its founder Muhammad ibn Abd al-Wahhab, originated in Saudi Arabia. It is a form of Salafi (puritan Islamist) ideology that believes in the strict and literal interpretation of the Quran; including the notion of jihad as a tool of warfare to bring about the original Islamist way of life. This theological movement is very different from the more tolerant Hanafi or the Sufi tradition originally found in South Asia. 
According to Alvi, Wahhabism's massive diffusion began in the 1970s when "Saudi charities started funding Wahhabi schools and mosques from Islamabad to Culver City, California". This is the religious ideology of all Islamist militant groups explored in this paper (Alvi, 2014).

The second wave of radicalization came during the Afghan War (1979-1992) when several Bangladeshis answered the metaphorical call to jihad and traveled to the war-ravaged country. At that time, the United States, along with Saudi Arabia and China, strongly supported the fight against the Soviet occupation in Afghanistan. Since Bangladesh received financial and development aid from the U.S. and Saudi Arabia, the Ershad regime once again turned a blind eye to the jihadists traveling to and from Afghanistan (Hasan, 2012). According to Fair et al. (2016), "returning militants brought with them their new knowledge of insurgent warfare and jihadist ideology to Bangladesh". Thereby resulting in the formation of the first generation of Sunni Salafi militant groups like Harkat-ul-Jihad-al-Islami (HUJI) (Fair et al., 2016). Founded in 1992, the majority of the members of HUJI were either Afghan War veterans or trained by them (U.S. Department of State, 2006). Osama bin Laden was the chief financier of the group in its infancy (Hasan, 2011).

Since the democratic election of 1991, the two mainstream political parties, BNP and AL, have engaged in the zero-sum game of political blaming and use of coercive means is an attempt to "deny each other's right to rule" (Seabrook, 2001). They have consistently denied the presence of jihadist groups, homegrown or foreign, in the county. Instead, the ruling party chose to point the finger at the opposition party for any terrorist incidents occurring during their regime. When out of power, both parties have boycotted parliament, called violent strikes and instigated shutdown of economic activities in retaliation to the decisions taken by the governing party (Siddiqi, 2011). This political instability resulted in the lack of proper institutions, rampant corruption in existing ones, and an ineffective system of law and order (Riaz, 2008). The subsequent issues of unemployment, poverty, illiteracy, and lack of scholarly discourse on religion compounded the spread of radicalization and Islamist militancy in Bangladesh, especially after the incident of $9 / 11$ (BEI, 2015). With more than half the diaspora below the age of 24 years (BBS, 2012), youth are the biggest victim of this phenomenon. Lack of access to basic resources and revenue generating opportunities makes them resentful of a polarized political structure that fosters income inequality and social entitlement (Khan, 2017).

The U.S. led War on Terror forced many jihadists to escape from Afghanistan and other known militant hubs to Bangladesh. The political, economic and social environment was highly conducive for refuge and operations (Singh, 2015). Time magazine reported that 150 Taliban and Al-Qaeda fighters from Afghanistan entered Bangladesh in December 2001 (Perry, 2002). This is the third wave of radicalization in the country. The severe political fragmentation left a vacuum enabling homegrown as well as absconding extremist outfits to gain a formidable presence in government. While BNP has allied with religious parties to win elections, AL espoused religious elements in their rhetoric for political gains. This foothold of Islamist parties in the political power structure gave leeway to jihadist groups. Due to the patronage enjoyed from the authorities, extremist militants could conduct their activities without any fear or hindrance (Singh, 2007). Also, the socioeconomic environment allowed for new members to be easily recruited using material gains, distorted Islamic ideology and the possibility of alternative political leadership (Rahman, 2016). An example is the formation of militant group Jamaat-ul-Mujahideen Bangladesh 
(JMB) in 1998. The group's association with BJI is notorious. JMB has engaged in several terrorist attacks in the early 2000s, including the 17 August 2005 serial bomb attack. With the aim of terrorizing the country into adopting Sharia Law, the group set off 459 bombs simultaneously in 63 of Bangladesh's 64 districts within the span of half an hour (The Indian Express, 2015). Similar incidents throughout the year, finally forced the government to proscribe certain main religious groups like HUJI and the JMB in 2005.

The fourth wave of radicalization in Bangladesh came from expatriate labor opportunities to Gulf region countries. Currently, the Arab nations account for 75\% of Bangladesh's migrant workers which amounts to 6 million Bangladeshi expatriates working in Saudi Arabia, the United Arab Emirates, Kuwait, Bahrain, Oman, Qatar, Libya, and Iran. In the 2009-2010 fiscal year, the remittance in Bangladesh amounted to US\$ 10.99 billion, of which US\$ 7.22 billion was sent by migrant workers in the Gulf region (Palma, 2011). Through this process, petrodollar along with the ultra-orthodox teachings of Wahhabism slowly crept into the everyday lives of Bangladeshis (Ahmed, 2015).

The pre-2006 trend of militancy in the nation saw homegrown militant organizations led by Afghan War veterans and the Taliban. These groups mostly recruited unemployed, male youths from poverty-stricken districts. From 2007 onwards, there was a military crackdown on Islamist violence during the caretaker government. A zero-tolerance policy was then adopted by AL when they were elected to power a year later. The result was a half-decade respite from Islamist militancy (Roul, 2016). But post-2013, there was an upsurge of extremist activity with a notably different trend. This led to the fifth wave of radicalization. Globalization in the information age and advancements in technology have broken down geographical, political and communication barriers. The dark side of this phenomenon has been to facilitate the spread of jihadist movements like al-Qaeda and ISIS, to all corners of the world including Bangladesh. More of this phenomenon is explored in the next section.

\section{THE RIVALRY BETWEEN ISIS AND AQIS}

The Indian subcontinent wing of Al- Qaeda (AQIS) has been a long-term hazard to Bangladesh's security landscape due to its comparatively wider local network. AQIS is primarily represented by Ansarullah Bangla Team or Ansar al Islam (ABT), a banned Bangladeshi Islamist outfit that first came into the limelight in 2013. AQIS propaganda is not only readily accessible online but is also available in the local Bengali language. The group is also rapidly developing the capacity to produce explosives on its own in Bangladesh (Bashar, 2017). AQIS has taken responsibility for some prominent murders, including the death of a LGBT activist and a USAID Bangladesh staff, Xulhaz Mannan, and his friend Samir Mahbub Tonoy in Dhaka, Bangladesh on 25 April 2016 (Khan, 2017).

AQIS and its affiliates had already had a growing grip on the nation since 2013 when IS decided to establish its footprints in Bangladesh in 2015. Earlier in 2016, the 14th issue of IS propaganda magazine, Dabiq, included two features on Bangladesh. One of these was an alarming interview of Bangladeshi ISIS recruiter and organizer Abu Ibrahim al Hanif, aka Canadian-Bangladeshi citizen Tamim Chowdhury. He spoke elaborately of the geographic significance of Bangladesh for expanding the group's activities to India and Myanmar. The Bangladesh-Myanmar border is a vulnerable place, and almost all terrorist groups in Bangladesh employ the Rohingya crisis in their recruitment rhetoric. This prominent rise of IS in Bangladesh can be mapped throughout the year. There have been a dozen targeted assassinations of atheist bloggers, university professors, foreigners, and people from 
religious minorities. However, the group conducted its most lethal attack on 1 July 2016 on the Holey Artisan Café in the diplomatic zone of Dhaka, the country's capital. In this attack, 20 hostages, mostly foreigners, and two policemen were killed by young ISIS recruits of Bangladeshi nationality (Bashar, 2017). Within less than a week of this event, an ISIS-inspired bombing took place during the largest Eid al-Fitr gathering at Sholakia ground in Kishorganj. The main targets of this incident were the 100,000 people there celebrating the end of the holy month of Ramadan. Fortunately, the perpetrators were apprehended in the middle of carrying out the attack but not before they detonated one of the bombs killing two police officers and two civilians as well as injuring several others (Wolf, 2016).

The rivalry between AQIS and IS is driven by the common nature of their objectives and target members in Bangladesh. Both groups wish to reestablish the original Islamic caliphate with Sharia Law in the Indian subcontinent. Thus the geological location and Sunni majority population of the soft state of Bangladesh greatly appealed to the jihadist movements. Also, unlike traditional militant outfits, AQIS and IS are both targeting male and female youth who are well-educated, from urban, middle-class background and proficient in modern technology. This recruitment strategy is adopted by both groups to improve the quality of their members. As a result, AQIS and IS are now competing for power, recruits and financing in Bangladesh. Indeed, the secondary objective of each group is to resist the extremist supremacy of the other in the country (Khan, 2017).

While AQIS collaborated with and took in ABT operatives to further its cause, IS maintained a strong online presence and "outsourced" its activities to JMB. Thus far, IS's social media campaign and recruitment have proven to be more effective than AQIS's live presence and full-fledged camps in Bangladesh. IS has successfully brought in the disgruntled splinter groups under its umbrella. However, given the geographical distance between IS's primary base of operations, it is may be more difficult to provide arms and training to its recruits in Bangladesh. In contrast, AQIS's geographical proximity to Bangladesh facilitates the provision of physical and functional support to ABT required to be functionally sustainable (Reed, 2016).

The potential consequence of this rivalry presents two scenarios. First, the escalating competition between the two groups may result in mass killing and destruction. Ibrahim al Hanif had also announced the group's plans to expand into Bangladesh in his interview. He stated that not only was IS going to concentrate on eliminating atheist or secular bloggers in Bangladesh, but also orchestrate large attacks to augment its capabilities among local jihadists (Mahmood, 2016). AQIS may respond to the encroachment of IS in Bangladesh with full force in order to re-establish its territorial prominence. This race of which group can radicalize more people and orchestrate the biggest, most deadly attack will grossly threaten the national and social security of Bangladesh. Second, increased infighting between the two groups may serve to weaken their resources and resolve. Such was the case with the Indian Mujahideen (IM). Intra and inter-group rivalries fragmented the group into two separate factions; one side allied with al-Qaeda and the other with IS (Reed, 2016).

\section{Conclusion and Recommendations for CounterterRorism}

The current government under Prime Minister Sheikh Hasina has been effective in containing jihadist forces in Bangladesh. Apart from bringing the war criminals to justice, security forces have dismantled radical groups and killed about 40 suspects, including 
some masterminds of the July 2016 restaurant attack (The Daily Star Lebanon, 2017). According to international terrorism expert Professor Rohan Gunaratna, Bangladesh can be viewed as "a model in delivering operational response against terror". This position can be attributed to three factors. First, the Prime Minister has directly empowered authorities to crack down on Islamist militants. Second, a specialized counterterrorism unit has been established to combat the growing problem of radicalization. Third, community engagement has been a prime focus in fighting extremism. However, there is a long way to go for Bangladesh to permanently counter the root causes of this issue.

As the youth of the nation are most susceptible to radicalization, special attention should be given to this demography. Those under 20 years of age spend half their time in cyberspace. International jihadist movements like IS and AQIS have utilized this behavioral pattern to spread fundamentalist propaganda and grow their network through the internet. Although Bangladesh has adopted the hard approach to counter the radical ideology in the physical space, further action needs to be taken to fight the online wave of extremism. Professor Gunaratna suggests the government should support the police and intelligence agencies to neutralize all networks (Azad, 2017).

A comprehensive and multi-institution anti-radicalization program should be launched in schools, universities, madrassahs and youth organizations across the country. Counseling, raising awareness, vocational training, and extracurricular activities can be a part of this approach. The main aim should be to counter jihadist propaganda with correct messaging, intellectual discourse on religion and community building. Families and society members should be educated on the dangers of religious extremism and the importance of providing support to vulnerable youths. They must also be taught to be vigilant about monitoring and reporting jihadist rhetoric or activities in mosques, madrassahs or neighborhood facilities. Here, the media and local government can be especially useful in raising public awareness against radical ideology and broadcasting the necessary counteractions. Most importantly, imams, religious leaders and teachers of Islamic institutes must be monitored by the authorities for radical narratives. They must be indoctrinated in the pacifist and tolerant ways of Islam and equipped with the resources to rescue youths, students, or the general masses who are verging on the path of radicalization.

Non-Government Organizations (NGO) and civil society can also be approached for assistance in three ways. Firstly, they can assist the NGO Affairs Bureau, Bangladesh Bank, and intelligence agencies in tracking and reporting terrorist financing operations that happen at the grassroots level. Secondly, their access to and knowledge of the people at the bottom of the pyramid allows them to spread the counter-narrative on religious fundamentalism effectively. Lastly, they can provide aid, income generating opportunities and community engagement activities for the disenfranchised and impoverished youth (Rahman, 2016).

Since 2004, approximately 3,000 Islamist radicals have been captured and imprisoned. Once released, these individuals will continue to spread the radical ideology and re-join their respective militant outfits. Professor Gunaratna states that unless these individuals are rehabilitated, the spread of extremism will not end. The de-radicalization process should start with engaging imams and religious teachers to convey the right messaging. Also, counseling should be provided to eliminate years of hatred and intolerance. As these radicals are disenfranchised and isolated, social and familial re-connection is another crucial element. Recreational rehabilitation through sports and cultural activities would be beneficial towards building a sense of community. Finally, vocational training and 
government aided jobs should be made available for when they come out of prison, and after they are de-radicalized (Azad, 2017).

From the findings in this paper, it can be concluded that religious ideology is but one aspect of terrorism. Indeed, it is driven more by political, social, economic and psychological elements. The recommendations provided are based on a holistic approach that takes into account the multifaceted and complex nature of religious terrorism. The government alone can't incorporate these changes without the cooperation and engagement of the private sector, NGOs, and the general public. The need for action and collaboration is more severe now than ever. The destructive nature of IS and AQIS has created a merging of interests. The country as a whole must seize the opportunity to rally together in an effort to defeat the heinous forces of terrorist groups and preserve the interests of its citizens.

\section{References}

Abadie, A. 2006. "Poverty, Political Freedom, and the Roots of Terrorism." American Economic Review 96.2: 50-56.

Ahmed, I. 2015. "Arab Awakening and Its Impact on Bangladesh." Contemporary Review of the Middle East 2 1-2: 119-134.

Alvi, H. 2014. "The diffusion of intra-islamic violence and terrorism: The impact of the proliferation of salafi/wahhabi ideologies." Middle East Review of International Affairs 18. 2: 38-50.

Asian Development Bank. 2017. Bangladesh and ADB. Accessed April 16, 2017. https://www.adb.org/countries/bangladesh/main

Azad, M. A. K. 2017. "What Bangladesh needs to do." The Daily Star. March 19. Accessed April 22, 2017 http:/ / www.thedailystar.net/opinion/interviews/what-bangladesh-needs-do-1377898.

Bashar, I. 2017. "Countering terror in Bangladesh." East Asia Forum. January 5. Accessed February 20, 2017. http:/ / www.eastasiaforum.org/2017/01/05/countering-terror-in-bangladesh/

BBC News. 2016. "Bangladesh War Crimes Trial: Key Accused". BBC News.com. September 4. Accessed April 20, 2017. http://www.bbc.com/news/world-asia-20970123

BBC News. 2017. Bangladesh Profile - Overview. March 2. Accessed April 10, 2017. http://www.bbc.com/news/world-south-asia-12650940.

BBS. 2012. Sample Vital Registration System 2012 (English). Accessed May 8, 2017. http:/ /203.112.218.65/WebTestApplication/userfiles/Image/Keyfinding/Key_Indi_SVR_Eng_ 2012.pdf

BBS. 2012. Sample Vital Registration System 2012 (English). Accessed May 10, 2017. http://www.bbs.gov.bd/WebTestApplication/userfiles/Image/Keyfinding/Key_Indi_

SVR_Eng_2012.pdf

BEI. 2015. The role of education in countering radicalization in Bangladesh. Dhaka: Bangladesh Enterprise Institute. Accessed April 30, 2017: http://bei-bd.org/wpcontent/uploads/2015/05/The-role-ofeducation-in-countering-radicalization.pdf

Esposito, John L. and John O. Voll. 1996. Islam and Democracy. New York: Oxford University Press.

Fair, C. C., Hamza, A. and Heller, R. 2016. "Who Supports Islamist Militancy in Bangladesh: What the Data Say?."

Fair, C. C., Littman, R., Malhotra, N. and Shapiro, J. N. 2016. "Relative Poverty, Perceived Violence, and Support for Militant Politics: Evidence from Pakistan," Political Science Research and Methods. Accessed April

15 , 2017. http:/ /journals.cambridge.org/action/displayAbstract?fromPage=online\&aid=10188983\&fileId $=$ S2049847016000066 
Gates, S. 2002. "Recruitment and Allegiance: The Microfoundations of Rebellion." Journal of Conflict Resolution 46.1: 111-130.; Dal Bó, Ernesto and Pedro Dal Bó. 2011. "Workers, Warriors, and Criminals: Social Conflict in General Equilibrium." Journal of the European Economic Association 9.4: 646-677.

Gurr, T. R. 1970. Why Men Rebel. Princeton, NJ: Princeton University Press.

Hasan, M. 2011. "Historical Developments of Political Islam with Reference to Bangladesh." Journal of Asian and African Studies 47.2: 161.

Hasan, M. 2012. "The Geopolitics of Political Islam in Bangladesh." Harvard Asia Quarterly 14.1-2: 60-69.

Horowitz, D. L. 1985. Ethnic Groups in Conflict. Berkeley: University of California Press.

Huque, A. S. and Akhter, M. Y. 1987. "The Ubiquity of Islam: Religion and Society in Bangladesh." Pacific Affairs 60: 200

Khan, S. E. 2017. "Bangladesh: The Changing Dynamics of Violent Extremism and the Response of the State". Small Wars \& Insurgencies 28:1. 191-217.

Khan, Z. R. 1976. "Leadership, Parties and Politics in Bangladesh," The Western Political Quarterly 29: $102-125$

Mahmood, A. 2016. “AQIS v IS: Battle for Bangladesh?" Dhaka Tribune, June 12. Accessed March 19, 2017. http:/ / www.dhakatribune.com/bangladesh/2016/apr/29/aqis-v-battle-bangladesh

Palma, P. 2011. "Arab unrest may affect economy". The Daily Star. Accessed May 1, 2017. http:/ / archive.thedailystar.net/newDesign/news-details.php?nid=179136

Perry, A. 2002. Deadly Cargo. Time. Accessed February 20, 2017. http://content.time.com/time/magazine/article/0,9171,364423,00.html

Piazza, J. A. 2007. “Draining the Swamp: Democracy Promotion, State Failure, and Terrorism in 19 Middle Eastern Countries." Studies in Conflict \& Terrorism 30.6: 521-539.

Rahman, M. A. 2016. "The Forms and Ecologies of Islamist militancy and terrorism in Bangladesh." Journal for Deradicalization 7: 68-106.

Reed, A. G. 2016. "Al Qaeda in the Indian Subcontinent: A New Frontline in the Global Jihadist Movement?." International Centre for Counter-Terrorism Policy Brief 8.

Riaz, A. 2008. Islamist Militancy in Bangladesh: A Complex Web. London, Routledge.

Riaz, A. 2010. Religion and Politics in South Asia. London: Routledge

Roul, A. 2016. "How Bangladesh Became Fertile Ground For Al-Qa Ida And The Islamic State." CTCSentinel, May 25. Accessed April 20, 2017. https://www.ctc.usma.edu/posts/howbangladesh-became-fertile-ground-for-al-qaida-and-the-islamic-state

Roychowdhury, A. 2016. "Why Bangladesh is Executing Jamaat-e-Islami Leaders". The Indian Express. May 12. Accessed April 18, 2017. http://indianexpress.com/article/research/why-bangladeshis-executing-jamaat-e-islami-leaders-a-short-history /

Schendel, W.v. 2009. A History of Bangladesh. Cambridge: Cambridge University Press, https://doi.org/10.1017/CBO9780511997419

Scott, J. C. 1976. Moral Economy of the Peasant: Rebellion and Subsistence in South East Asia. New Haven: Yale University Press.

Seabrook, J. 2001. Freedom Unfinished: Fundamentalism and Popular Resistance in Bangladesh Today. London: Zed Books.

Siddiqi, D. M. 2011. "Political Culture in Contemporary Bangladesh: Histories, Ruptures and Contradictions." In Political Islam and Governance in Bangladesh, eds. Ali Riaz and C. Christine Fair. New York: Routledge.

Singh, B. 2015. "Islamic Fundamentalism in Bangladesh." Himalayan and Central Asian Studies 19.1-2: 57

Singh, R.N.P. 2007 Bangladesh Decoded. New Delhi, India First Foundation. 
South Asia Terrorism Portal. 2016. "Fatalities-Islamist Terrorism 2005 - 2016," June 26. Accessed February 20, 2017. http://www.satp.org/satporgtp/countries/bangladesh/database/FatalitiesIslamist $\% 20$ Terrorism $\% 202010 . h t m$

Swami, P. 2013. “What India can learn from Bangladesh's Jamaat-e-Islami ban." First Post, August 3. Accessed April 18, 2017. http://www.firstpost.com/world/what-india-can-learn-frombangladeshs- jamaat-e-islami-ban-1007303.html

The Daily Star Lebanon. 2017. "Another suspected mastermind in Bangladesh attack arrested". The Daily Star Lebanon. January 14. Accessed May 11, 2017. http:/ / www.dailystar.com.lb/News/World/2017/Jan-14/389394-another-suspectedmastermind-in-bangladesh-attack-arrested.ashx

The Indian Express. 2015. "A Look at Some Key Radical Islamist Groups in Bangladesh." 27 November. Accessed 21 April, 2017. http://indianexpress.com/article/world/worldnews/gunmen-attacked-a-shiite-mosque-in-bangladesh/

U.S. Department of State. 2006. Country Reports on Terrorism 2005. Accessed April 20, 2017: http://www.state.gov/documents/organization/65462.pdf

Wolf, S. O. 2016. "Escalating Jihadist Terror in Bangladesh-What Next?." SADF Comment, No. 25, South Asia Democratic Forum (SADF), Accessed February 20, 2017. https://ssrn.com/abstract=2834636

$$
\text { --0-- }
$$

